DOI https://doi.org/10.18551/rjoas.2020-12.11

\title{
LEGAL CONSIDERATION OF LEGAL CONVERSION IN DIFFERENT RELIGIOUS MARRIAGE IN INDONESIA
}

\author{
Romli Muhammad, Candidate for Doctor of Law \\ Faculty of Law, University of Brawijaya, Malang, Indonesia \\ Luth Thohir, Professor, Lecturer \\ Faculty of Law, University of Brawijaya, Malang, Indonesia \\ Sulistyarini Rachmi, Hamidah Siti, Doctors, Lecturers \\ Faculty of Law, University of Brawijaya, Malang, Indonesia \\ *E-mail: romlimuhammad31@gmail.com
}

\begin{abstract}
This article discusses the legal certainty of legal smuggling in interfaith marriages in Indonesia. Not a few who carry out interfaith marriages in Indonesia go abroad, even though this can be categorized as a form of legal smuggling due to avoiding the law that should apply to them. This research uses a conceptual approach, a statutory approach, a comparative approach and a philosophical approach. Legal materials used in this study consist of primary legal materials, secondary legal materials and tertiary legal materials which are normative in nature by searching, collecting, and studying literature and documents, both conventionally and via the internet. The result of this research is that interfaith marriages by Indonesian citizens conducted abroad are a form of legal smuggling because they are against the law of marriage in Indonesia based on religious law. Many countries, whether or not they have written regulations, generally do not condone or refuse legal smuggling. they prefer to keep their citizens in compliance with their national laws if there is an element that the smuggling of the law occurs then the marriage can be declared invalid. The Indonesian marriage law has not provided legal certainty for the smuggling of interfaith marriage laws, on the one hand there is no legality of marriage legality, on the other hand the marriage is still recorded in the registration.
\end{abstract}

\section{KEY WORDS}

Legal smuggling, legal certainty, interfaith marriage.

Humans are destined by the nature of zoon politicon, they always live in groups in a group called society. Living alone without one another somewhere, is not human nature as a creature (Isnaeni, 2016). Similarly, marriage is human nature as a living being, although in its implementation it varies in organizing it. In Indonesia, absolute marriage is legally based on religious law and this is reflected in Article 1 and Article 2 paragraph (1) of the marriage law which states: marriage is an inner birth bond between a man and a woman as husband and wife with the aim of forming a family (home ladder) that is happy and eternal based on the Almighty God. Marriage is valid, if done according to the law of each of his religions and beliefs. In case it is in line with the ideology of the Indonesian nation (pancasila) please unite, namely "Based on the Almighty God".

General interpretation in Article 2 paragraph (1) of the Marriage Law is not allowed as an Indonesian citizen to perform marriages outside of his religious law (Hazairin, 1986). It can also be understood from these provisions that the parties must have the same religion or belief, so that the marriage becomes valid according to their religion and only then can they register the marriage in the Office of Religious Affairs or in the Office of Civil Records. Such an arrangement occurs because Law No. 16 of 2019 Amendments to the Marriage Law Number 1 of 1974 on Marriage not only regulates marriage as a civil matter only, but also as a religious matter (article 2 paragraph (1). from these arrangements and interpretations that 
are generally applied, it is not possible for marriages to occur for parties of different religions or beliefs.

This clearly inhibits the desire of lovers who continue to wish to maintain their religious differences and formalize their relationship into marriage. Generally, these parties, if they have the economic capacity, will go abroad and get married in that country. The countries they choose are generally those whose marriage laws only regulate marriage as a mere civil relationship and do not regulate it as a religious issue (Abrams, 2006). In these countries, religious differences are not a requirement, let alone a barrier to progress. Therefore, parties with different religions or beliefs will be able to register their marriage in that country, and when they return to Indonesia as husband and wife legally according to foreign law, namely the law of the country where the marriage was carried out. By marrying civilians abroad, returning to Indonesia and registering their marriage at the Civil Registry Office in Indonesia, is a form of legal smuggling (Basuki, 2018).

In the Dutch language smuggling law is termed "Wetsontduiking", in the French term "fraud a la loi", while in the German term "Gesetzesumgehung". Almost every country has a term relating to smuggling of laws, but all of them almost have the same meaning that smuggling the law is an act or legal act of a person based on and using the words of the law, but against his soul and purpose, deceptively committing an act -conduct which is apparently carried out with the intention of circumventing written or unwritten legal principles.

The practice of smuggling law in the field of marriage as above by going abroad is mostly done for those who are legally unable to get married in Indonesia (Sopyan \& Dyana, 2017; Rismawati, 2017; Khairunnisa, 2018). After arriving in Indonesia they are required to register their foreign marriage with the registration of the marriage in their place of residence. With the registration of overseas marriages, whether legal smuggling problems in the field of marriage, especially interfaith marriages, are legally valid or vice versa, so far this has not provided legal certainty for this problem. This study aims to determine the legal certainty of legal smuggling in interfaith marriages in Indonesia.

\section{METHODS OF RESEARCH}

This study uses a conceptual approach, a statutory approach, a comparative approach and a philosophical approach. Legal materials used in this study consist of primary legal materials, secondary legal materials and tertiary legal materials which are normative in nature by searching, collecting, and studying literature and documents, both conventionally and via the internet.

\section{RESULTS AND DISCUSSION}

Arrangements for Marriage with Different Religions in Indonesia. Prior to the enactment of Law Number 1 of 1974 concerning Marriage, interfaith marriage was made possible through the Mixed Marriage Regulation (GHR) and $\mathrm{HOCl}$, namely by providing a broad understanding, then in Law Number 16 of 2019 the Amendment to the Marriage Law Number 1 of 1974 concerning Marriage, it is no longer possible to expand the meaning of Mixed Marriage by including interfaith marriages. The meaning of Mixed Marriage in Article 57 of Law Number 16 of 2019 Amendments to the Marriage Law Number 1 of 1974 concerning Marriage has been narrowed in such a way that what is meant by Mixed Marriage is the only marriage between two people who in Indonesia are subject to different laws, because of differences in nationality and one of the parties is Indonesian citizenship.

According to Hazairin, "Article 57 limits the meaning of Mixed Marriage between a citizen who is not a citizen of the Republic of Indonesia and a citizen of a non-Republic of Indonesia so that it does not include marriages between citizens of the Republic of Indonesia who are different from the law and between non-citizens of the Republic of Indonesia (Hazairin, 1986). ).

This was also stated by Masfjuk Zuhdi, that based on Article 7 of Law Number 16 of 2019 Amendments to the Marriage Law Number 1 of 1974 concerning Marriage, interfaith 
marriages in Indonesia are not mixed marriages. So that applications for interfaith marriage both at the Office of Religious Affairs (KUA) and the Population and Civil Registry Service should be rejected.

According to Purwoto S. Gandasubrata, mixed marriages or interfaith marriages have not been completely and firmly regulated in the law. Because of this, there is the Population and Civil Registry Office that does not want to register interfaith marriages on the grounds that these marriages are contrary to Article 2 of Law Number 16 of 2019 Amendment to Marriage Law Number 1 of 1974 concerning Marriage. There is also the Department of Population and Civil Registry that wants to record based on the Huwelijken Regeling, that marriage is carried out according to the husband's law, so that the wife follows the husband's legal status (Soedharyo, 2002).

If we pay close attention to Law Number 16 of 2019 Amendments to the Marriage Law Number 1 of 1974 concerning Marriage, there are several opinions regarding interfaith marriage, including the following (Ali, 1993).

The first opinion states that marriages between people of different religions can be carried out as the implementer of human rights and a person's freedom to determine his partner. According to this opinion, such a marriage can use Stb. 1898 No. 158 concerning Mixed Marriage, inherited from the Dutch before as a basis and to register it at the Civil Registry Office where they carried out the marriage. Religious differences, according to this opinion, should not be an obstacle to the implementation of the marriage. Civil Registry Office employees must not refuse to take notes, even have to "marry" people of different religions who are burning the fire of their love. According to them, the problem of marriage is a matter of life in society in this world, not a problem in the afterlife. Therefore, regarding the marriage of people of different religions, just leave it to the law created by humans to regulate it. To support their stance, they quoted the opinion of the late Professor of the Netherlands, Prof. W.L.C Lemaire, Director of the Institute for Legal Documentation Across the Ocean (as Indonesia is still part of the Netherlands, MDA) of Leiden University who said that "the task of law is to regulate order in people's lives, not to regulate the welfare and safety of the hereafter". This secular view was formulated in Article 11 paragraph (2) of the Marriage Law Draft (1973) which stated: "Differences due to nation, country of origin, religion or belief and descent are not a barrier to marriage", which the DPR rejected and excluded from the Law. - Marriage Law (1974) because "it is not in accordance with the basic philosophy of Pancasila and the 1945 Constitution of the Republic of Indonesia". In the end, Article 11 paragraph (2) of the Marriage Bill cannot be continued in the form of the Marriage Law, considering that many parties do not agree with Article 11 paragraph (2) because the basis of the Indonesian State is Pancasila in the first principle "Based on One Godhead".

The second opinion, said that article 57 of Law Number 16 of 2019 Amendment to the Marriage Law Number 1 of 1974 concerning Marriage implicitly regulates marriages between people of different religions, which is incorrectly referred to in Indonesian literature as "marriage between- religion". According to this second opinion, Article 57 of Law Number 16 of 2019 Amendments to the Marriage Law Number 1 of 1974 concerning Marriage as the author mentioned above, contains two explicit and implied meanings. The explicit meaning is formulated in Article 57, "what is meant by Mixed Marriage in this Law is a marriage between two people who are in Indonesia, subject to different laws, because of differences in nationality and one of the parties is Indonesian citizens". The meaning is implied in a comma after different words. The word "different laws" in that article includes marriage of people of different religions. Regarding the editorial and comma tucked into Article 57, a Professor of Indonesian Language from the Faculty of Letters, University of Indonesia, stated that Mixed Marriage as regulated in this article is Mixed Marriage between people of different nationalities, not marriage between different people. religion. With or without a comma tucked in there, the meaning is the same as it is written. In other words, it can be understood according to this second opinion, that interfaith marriages cannot be categorized as mixed marriages and can conclude that marriages cannot be carried out according to the Indonesian Marriage Law. 
The third opinion states that marriage between people of different religions is not desired by the legislators, namely the Government and the DPR of the Republic of Indonesia. This intention, among others, is expressly stated in Article 2 paragraph (1) of the Marriage Law Number 1 of 1974 concerning the validity of marriage based on religion as an embodiment of the precepts of One Godhead which is the basis of marriage in Indonesia as described above. Therefore, it is very logical that Article 8 letter (f) of the Marriage Law is clearly formulated that, "marriage is prohibited between two people who have a relationship which is prohibited by their religion and the prevailing regulations from being married". This means that Marriage Law Number 1 of 1974 prohibits the carrying out or legalizing of marriages that are prohibited by religion and other regulations in force in the Republic of Indonesia.

Interfaith marriage cannot be carried out in Indonesia, it turns out that it can be implicitly carried out by making a marriage for a couple of different religions abroad.

Based on Article 56 of Law Number 16 of 2019 Amendment to the Marriage Law Number 1 of 1974 concerning Marriage which regulates marriages abroad, it can be carried out by fellow Indonesian citizens, and marriages between couples of different religions are legal if done according to the law in force in which the marriage takes place. According to the provisions of Article 56 paragraph (2) Law Number 16 Year 2019 Amendments to the Marriage Law Number 1 Year 1974 concerning Marriage, after the husband and wife return to the territory of Indonesia, at least one year proof of marriage can be registered in The Marriage Registration Office where they live. However, strictly the Marriage Law only regulates the registration of marriage, divorce and reconciliation, which means that the procedure is not legal material. Marriages carried out abroad by Indonesian citizens of different religions are still an act of legal smuggling, as both partners try to avoid national law. The marriage is indeed legal according to the laws of the State where the marriage is carried out, but it is not in accordance with the provisions of Law Number 16 of 2019 Amendments to the Marriage Law Number 1 of 1974 concerning Marriage in effect in Indonesia. On the other hand, Law Number 16 of 2019 Amendment to the Marriage Law Number 1 of 1974 concerning Marriage in no way provides a prohibition on marriages conducted by couples of different religions. If indeed interfaith marriage is not allowed, then this should be confirmed in the law. Religious law is still a religious principle that is included in positive national law. Therefore, religious principles cannot be applied indirectly in law because they involve the general public.

The Nature of Legal Smuggling. All the incidents previously described in relation to smuggling of laws have the same character, namely that international civil law has been used for a specific purpose, namely so that the legal relationship in question is treated differently than what should have been used if circumventing measures were not taken. The purpose of the actions concerned is to be able to avoid an unwanted legal consequence or to realize a desired legal result. So what we see is that there is always a subjective element, namely in the form of the intention or intention to smuggle in. There are abnormal ways to achieve that goal. There has to be an extraordinary way, a way that displays a trickery. He carries out a certain legal action, but he wants another legal effect to be realized (Gautama, 2007).

The motivation of the parties determines whether a legal action becomes a choice of law or legal smuggling. This motivation occurs because of the existence of a national legal arrangement which, according to them, will hinder the achievement of certain goals they want. This may be because national law expressly prohibits or does not declare illegal acts of law for the purpose of public order, or because national law politics seeks to regulate the achievement of certain goals. This is generally not explicitly formulated in positive legal regulations (Basuki, 2018).

A well-known example of a marriage that is a law smuggling is marriages which in the international civil law literature are commonly known as Gretna Green marriages. Gretna Green is a village located in Scotland. This village was once known as a refuge for British people who wanted to get married without their parents' consent. In order to get married at Gretna Green, it is enough for a British couple to stay twenty-one days before the marriage 
takes place. Although England and Scotland are the same country, there are positive legal differences between them. English law is not as territorial in force as Scottish law. After these conditions of stay are met, they can carry out a local legal marriage. Since the 1939 Scotland Marriage Act came into force, the conditions for marriage have been tightened so that it is no longer possible to carry out a marriage by law smuggling.

It is clear that the person who smuggles this law has bad intentions. They want to circumvent certain legal principles and the consequences thereof. For this they created a determining link point "frauduleus". These link points have been changed intentionally. What had previously been the determining point of connection was avoided and other link points were used so that the law being treated also changed in line with the party that was created or changed by the person concerned. This is explained in the example above, where changes are made from the linking point of citizenship and / or residence, solely to be able to get married or divorce easily (Gautama, 2007).

Legal Certainty against Smuggling of Marriage Laws of Different Religions in Indonesia. Marriages of Indonesian Citizens (WNI) carried out abroad are one of the objects of international civil law regulation. Where is the international civil law according to Prof. Sudargo Gautama are:

"All regulations and legal decisions that show which legal system is applicable or what constitutes law, if the relationships or events between citizens (citizens) of the state at a certain time show the points of connection with the systems and legal rules of the two or more countries, differing in spheres of power, place, personality, and matters. So here what is emphasized is the difference in the power environment of the place and the problems as well as the differentiation in the system from one country to another, meaning that there is a foreign element.

Foreign elements in a marriage are contained in Article 56 (1) and (2) of the Marriage Law which states that marriages between Indonesian citizens outside Indonesia are legal if they are carried out according to the law in force in the country where the marriage is taking place and for Indonesian citizens it does not violate the provisions of the Marriage Law and a record is required one year after marriage. The legal requirements for marriage to be carried out abroad are reflected in the material and formal requirements that can determine the validation of marriage based on the principles of international civil law (Hardjowiyono, 2013).

Material requirements are based on lex loci celebrationis, personality status and principles that state that material law is based on the legal system of the place where the marriage was held (locus celebration) without neglecting the marriage requirements that apply in the legal system of the parties. Thus, in implementing law, it still refers to the two legal systems inherent in the parties. Meanwhile, the formal requirements for marriage are determined by the principle of locus regit actum, which is based on the law of the place where the marriage takes place (lex loci celebration). Article 56 of the Marriage Law states "when it is carried out according to the applicable law in the country where the marriage is carried out".

Basically, the implementation of marriages abroad by Indonesians of different religions is a form of effort to seek the legitimacy of their marriages, where in international civil law the principle of vested rights applies. The term vested rights is often referred to as rights and obligations created abroad or legal rights and obligations issued under foreign law. This principle is closely related to the recognition of what has been owned by, or has become a right, or which has been legally attached to a legal subject.

The legal rights and obligations that a person has obtained based on a rule of law must be respected by anyone, including by lex fori (the law of the judge) unless recognition of such rights will result in consequences that are contrary to the public order of the forum community. . This view or principle developed at the height of the individualistic view of life which considers that a person's "property right" has absolute legal force so that it is necessary to obtain absolute protection anywhere and against anything.

In line with the development of "property rights that function socially", the insight into the doctrine of vested rights has also shifted and people tend to adhere to this teaching in a limited way (qualified). The definition of vested rights in a limited sense, namely the rights 
owned by a person based on foreign legal principles can be recognized as long as the recognition does not conflict with public order lex fori.

Based on the concept of international civil law, legal smuggling is an act that is committed in a foreign country and is legally recognized in that foreign country. This act can be canceled by the forum or not recognized by the forum if the act is carried out in a foreign country with the aim of circumventing the lex fori law which would prohibit such acts being carried out in the forum area.

The purpose of this action is to avoid legal consequences that the parties do not want or to bring about a legal consequence that they want.

According to scholars, there are two points of view regarding the problem of legal smuggling, namely based on the objective and based on the subjective. For those who view this from an objective point of view, it is required that the action concerned, which is in accordance with a letter rather than a law, is contrary to its soul and purpose. According to this standpoint, it is not important what the intent of the person concerned is. He can also assume in good faith that what he is doing does not violate the relevant law. The subjective intention of the person concerned does not always need to be considered the determining factor. Isn't this true on the one hand that the person concerned intently intends to smuggle one law but on the other hand at the same time wants to conquer himself under another law? Those who can only feel that they are being disadvantaged are legislators.

On the other hand, the subjective stance places emphasis on the bad intentions concerned. Apart from requiring that the act concerned must be contrary to the spirit and meaning of the law, it is again required that this act must have the intention of deception based on the letter of the law to escape from the bonds of this law by committing the acts concerned.

The intention of the parties concerned is important in determining whether there has been legal smuggling or not. Only after it turns out that the intentions are not good can we determine whether the series of facts that constitute this material is legal smuggling or not. After we can ascertain the intention of the person concerned from the facts, we can see something clearly, then it will appear that what has been done right is a form of legal smuggling. Without a description, the facts given are not clear enough. We have not been able to determine with certainty whether what is faced is a legal smuggling incident or not.

The motivation of the parties determines whether a legal action becomes a choice of law or becomes a legal smuggling. This motivation occurs because of the existence of a national legal arrangement which they think will hinder the achievement of certain goals they want. For example, we can look at the problem of interfaith marriage. The marriage law stipulates that a marriage is legal according to the religion and belief of the parties. The general interpretation of this provision is that the parties do not have a marriage outside the law of their religion and belief, and almost all religions require the same religious marriage.

After the marriage of the parties is legal according to their religion and belief, only then can the parties register the marriage at the Religious Affairs Office for Muslims and the Civil Registry Office for those who are not Muslim. This arrangement occurs because the Marriage Law does not merely regulate marriage as a mere civil matter, but also as a religious matter. As a result of this arrangement and the interpretation in general applied, it is not possible to have marriages for parties of different religions. This will clearly hamper the desire of those who want to get married but have a different religion. In general, parties with more economies would prefer to go abroad to be able to have interfaith marriages. And in general, the parties will choose a country which by marriage law only regulates marriage as a civil relationship and does not regulate it as a religious issue (Basuki, 2018).

Returning again to Article $16 \mathrm{AB}$, with regard to personal status (including marriage) wherever a person with the status of an Indonesian citizen travels, the Indonesian national law (marriage law) still applies to them. By marrying civilian abroad, returning to Indonesia and registering the marriage at the Civil Registry Office in Indonesia, is a form of smuggling law. 
Cases like the one above do not only occur in Indonesia, but in almost many countries. Some of these countries include Argentina, France, Canada, Switzerland, Egypt and socialist countries.

In Argentina there are rather "favorable" provisions for marriages that have been held abroad with a view to circumventing the excessively restrictive provisions of its national law. As for what is meant is Article 159 B.W. Argentina in 1869. Article 1207 B.W. but upholds a different principle regarding covenants. If an agreement has been entered into abroad with the aim of violating the laws of the Republic of Argentina, then the agreement is null and void, also if according to the lex loci actus (the law of the place where it was executed) this agreement is valid.

Likewise Article 1208 B.W. determine that treaties which have been made inside Argentina with the intention of violating foreign law are not valid.

With these last two articles, the Argentine lawmaker has explained his stance that fraus legis in the field of treaty law results in that the legal acts concerned are not valid. On the other hand, in the field of marriage perpetuation, the stance of Argentine legislators is lenient (Gautama, 2007).

French law rules which are public ordre, the French law rules will be used. As long as the rule of foreign law is not different from the rule of French law, then the rule of law applies. It's just that the rule of law is not based on foreign legal rules, but French law. If a foreign legal rule is different from French law, then the French judge will put aside the foreign legal rule and apply French law instead (Basuki, 2018).

France, which does not have HPI regulations in a separate codification, does not recognize the written formulation of Fraude a la loi, which develops jurisprudence and prudence. In France, it is famous for its adage that is used as a guide in dealing with legal smuggling problems, namely fraus Omnia Corrumpit. Actions of legal smuggling bring all sanctions to be canceled, both actions for legal smuggling and other consequences. In the case of Princes Bauffremont this argument has been clearly outlined. There is a defaut de sincerite which has become a guideline for seeing all these legal smuggling arrangements as void.

Article 25 expressly determines that no one can use a legal condition which was created with the intention of claiming the validity of foreign law. The sanction for the cancellation of legal acts aimed at smuggling French legal principles is stated in so many words. With regard to marriage, the French regulation in Article 64 provides that a marriage of a foreigner in France can be declared null and void if it has been carried out for the purpose of smuggling out the conditions announcing the essential of his personal status.

In line with this Article 70 stipulates that marriages of French persons abroad can be declared null and void if they have been carried out with the intention of smuggling in the rules of French law. This marriage provision differs from Argentine law which provides soft regulations against smuggling laws in the field of marriage.

These terms of marriage are different from what we see in B.W. Argentina, which is more lenient in marriage smuggling. Meanwhile in France the adagium fraus Omnia corrumpit still has a big influence.

In Canada there is the province of Quebec, there are also provisions relating to marriages abroad which are intended to smuggle regulations on formalities overseas. In the provisions of the Quebec marriage law Article 135 states that a marriage which is entered into abroad between a person who both or one is subject to the Quebec regulations is subject to formalities there and is recognized as legal except where the parties have no intention of smuggling. laws by traveling abroad. In other words, Quebec law will provide recognition of the legality of the marriage of Quebec citizens abroad as long as it does not conflict with Quebec regulations.

In the State of Switzerland, special provisions regarding the smuggling of laws relating to the continuation of marriages abroad have been recognized. Article $7 f$ of the NAG (2561891 ) provides that a marriage which is carried out abroad according to the law which takes place in the State where the marriage is held is considered as legal in Switzerland if it is not evident that it was carried out for the purpose or motivation of smuggling Swiss law. In this 
case, if there is a marriage of a Swiss citizen outside the territory of the State of Switzerland, it is lawful if according to the provisions of the law of the State where the marriage is carried out, provided that it does not explicitly contradict the terms of the non-validity of the marriage in Switzerland.

Some Muslim countries in the world already have an independent codification of Civil International Law (HPI), and some do not yet have an HPI codification. However, that does not mean that they do not know and operate their respective HPIs, for example Muslim countries are Egypt, Syria, Turkey.

In the Egyptian Zivilgesetbuch in 1948, there were various provisions which were of an Inter-Time Law, in addition to those of the HPI. The Egyptian HPI system is structured in B.W. This Egypt. Among them are international provisions regarding private law such as marriage law, inheritance, property and contract law. There are also provisions that fall into the field of general theories about HPI. It regulates qualifications, the attitude that must be taken when appointed to the law of a State that has a pluralistic civil law system, regarding re-appointment (Article 27) and regarding public order.

Article 28 of the Egyptian Civil Code regulates this public order. The article is short in wording. It is determined that the use of foreign law is according to the principles stipulated in articles B.W. previously mentioned that this Article is not possible if these foreign rules violate public order or bad morals prevailing in Egypt. Thus, Egyptian citizens cannot use foreign laws (one of which is the law of marriage) when those laws conflict with public order or Egyptian national law. In other words, the Egyptian state rejects the existence of illegal smuggling (Gautama, 2007).

Apart from Egypt, the State of Syria also has a rather complete codification for its HPI. This codification has been emulated from Egypt. The State of Syria has adopted the Egyptian Civil Code. In particular, it does not directly mention the provisions of legal smuggling, but in Article 30 as a closing article it clearly states that the use of foreign law according to the preceding articles is impossible if the foreign rules concerned violate public order or morality in Syria. It can be understood that the Syrian State is unlikely to accept foreign laws if these laws conflict with public order, in this case the Syrian national law, including in the field of marriage law (Gautama, 2007).

Meanwhile, the State of Turkey does not yet have a complete codification regarding HPI. The Turkish state only has provisions regarding HPI which are scattered among various other regulations.

Article 2 provides that the laws of the Turkish State which are in the field of police and public order also apply to foreigners who are in the territory of the Turkish State. What is stated in this article is in accordance with the general teaching regarding the HPI theory as adopted in various countries. Criminal or administrative law principles including public law apply to Turkish citizens and foreigners residing in Turkey. The rules which are considered to be of the nature of public order are equated with the rules of public law.

In Article 4 that all cases relating to foreigners who are not Muslim related to family law such as marriage, divorce, child relations, will only be brought to the Turkish court if the parties jointly request it or if the Turkish citizen concerned is involved in it for at trial court Turkey. In this case as long as it does not conflict with public order prevailing in Turkey, then the case will be tried according to the law of their respective citizens. In other words, Turkey in determining personal status based on the principle of nationality as long as it does not conflict with public order or Turkish national law. Although it does not mention directly regarding the smuggling of laws, from the regulation it is clear that if a foreign law conflicts with Turkish public order then the foreign law cannot be enforced, in the word other is invalid.

Countries belonging to the Socialist group generally cannot justify the smuggling of laws. The famous Soviet writers Pereterski and Krylow argued that it was self-evident that the smuggling of Soviet law had to be overridden by the establishment of the soviet HPI. Legal acts which constitute a form of legal smuggling cannot be applied. This is explained by the provisions of Article 30 of the Soviet Civil Code.

According to Article 30 all legal actions intended to smuggle the law or have causes that violate the law are invalid. In line with this are the provisions contained in the Civil Code 
of various states. This also applies to foreign link point events. Also in Article 7 of the Soviet Civil Code there is a provision that prohibits the smuggling of Soviet law.

In the case of marriage in the Soviet Union the need for legal smuggling was not so great, because as far as Soviet marriage and divorce were concerned, there was no barrier which was felt to be so restrictive to the citizens of the Soviet state that it was necessary to find a way to smuggle the law.

There are many other countries that cannot be mentioned in this explanation, but this does not mean that in countries not mentioned here there are no known legal smuggling problems. If there is no written regulation regarding this matter, it does not mean that the legal smuggling issue is not recognized in the HPI of the country concerned. When compared between countries that recognize written regulations regarding legal smuggling and those that do not, then there are far more countries that do not have written regulations even though the problem is enforced.

Of the many countries mentioned above, both those that have written regulations or not, generally do not justify or reject the smuggling of laws. Of the several states that have been mentioned regarding the State's attitude towards smuggling of the law, they are more likely to protect their citizens to comply with their national laws in the case of marriages that are carried out abroad and if there is an element that there is legal smuggling, the marriage can be declared invalid.

In Indonesia, the law of smuggling of interfaith marriages has not been confirmed (there is no legal certainty) regarding this act, on the one hand interfaith marriages have not validated interfaith marriages, on the other hand these marriages are recorded in their registration.

In the future regulations (Indonesia) it must be regulated whether the act of smuggling the law is carried out abroad, the law can firmly accept its validity or not. Thus, if the future regulations regulate marriages that are held overseas are subject to the principle of lex loci celebrationis by still upholding public order so that they can provide solutions to community problems so far and do not cause legal conflicts. In general, it can be understood that interfaith marriages between Indonesian citizens who are carried out abroad when returning to Indonesia are contrary to the public order in force in Indonesia, if they violate public order they can be categorized as a form of legal smuggling.

\section{CONCLUSION}

The results of this study are interfaith marriages by Indonesian citizens carried out abroad are a form of legal smuggling because they are contrary to the law of marriage in Indonesia which is based on religious law. Many countries, whether or not they have written regulations, generally do not condone or refuse legal smuggling. they prefer to keep their citizens in compliance with their national laws if there is an element that the smuggling of the law occurs then the marriage can be declared invalid. Indonesian marriage law has not provided legal certainty for the smuggling of the law of interfaith marriage, on the one hand there is no legality of marriage legality, on the other hand such marriages are still recorded in registration. In a future regulation (Indonesia), it must be regulated whether the act of smuggling the law is carried out abroad, the law can firmly accept its validity or not. Thus, if the future regulations regulate marriages that are held overseas are subject to the principle of lex loci celebrationis by still upholding public order so that they can provide solutions to community problems so far and do not cause legal conflicts.

\section{REFERENCES}

1. Abrams, K. (2006). Immigration law and the regulation of marriage. Minn. L. Rev., 91, 1625.

2. Ali, D. M. (1993). Perkawinan Campuran Antara Orang-orang Berbeda Agama.

3. Basuki, Z. D. (2018). Hukum Perdata Internasional. Tangerang: Universitas Terbuka. 
4. Berman, L. (1921). The Glands Regulating Personality: A Study of the Glands of Internal Secretion in Relation to the Types of Human Nature. Macmillan.

5. Gautama, S. (2007). Hukum Perdata Internasional Indonesia. Bandung: PT. Alumni.

6. Hardjowiyono, B. S. (2013). Dasar-Dasar Hukum Perdata Internasional, Bandung: Citra Aditya Bakti.

7. Hazairin. (1986). Tinjauan Menegenai Undang-undang Perkawinan Nomor 1 Tahun 1974. Jakarta: Tintamas.

8. Isnaeni, M. (2016). Hukum Perkawinan Indonesia. Bandung: Refika Aditama.

9. Khairunnisa, F. (2018). The Authority on Endorsement Of Marriage Agreement Between Indonesian And Foreign Citizen Which Made Abroad. Unram Law Review, 2(2), 108-125.

10. Rismawati, S. D. (2017). Choosing One Religion and Getting Married: The Meaning and Legal Culture of Interfaith Marriages Couples in Purbo Pekalongan, Indonesia. Jurnal Hukum dan Pembangunan, 17, 235-243.

11. Soedharyo, S. (2002). Hukum Orang dan Keluarga. Jakarta, Sinar Grafika.

12. Sopyan, Y., \& Dyana, B. (2017). Marriage Legalization For Indonesian Migrant Workers (Implementation of" Justice for All" for Migrant Workers at Tawau, Sabah, Malaysia)(Implementation of" Justice for All" for Migrant Workers at Tawau, Sabah, Malaysia). In 1st International Conference of Law and Justice-Good Governance and Human Rights in Muslim Countries: Experiences and Challenges (ICLJ 2017). Atlantis Press. 